\title{
Lahars of Mount Pinatubo, Philippines
}

n June 15, 1991, Mount
Pinatubo in the Philip-
pines exploded in the second
largest volcanic eruption on
Earth this century. This
eruption deposited more than
1 cubic mile (5 cubic kilome-
ters) of volcanic ash and rock
fragments on the volcano's
slopes. Within hours, heavy
rains began to wash this
material down into the sur-
rounding lowlands in giant,
fast-moving mudflows called
lahars. In the next four rainy
seasons, lahars carried about
half of the deposits off the
volcano, causing even more
destruction in the lowlands
than the eruption itself.

Background

Before April 1991, when steam explosions blasted out three small craters on the north flank of Mount Pinatubo on the island of Luzon in the Philippines, the volcano had been dormant for 500 years, allowing lush tropical vegetation to cover its slopes. Eventually, the population of the region grew to nearly 1,000,000 people, as towns, cities, and hundreds of villages, as well as the largest U.S. military base in the Philippines (Clark Air Base), were built on the broad gentle slopes surrounding the volcano.

When Pinatubo reawakened in April 1991, scientists from the Philippine Institute of Volca-

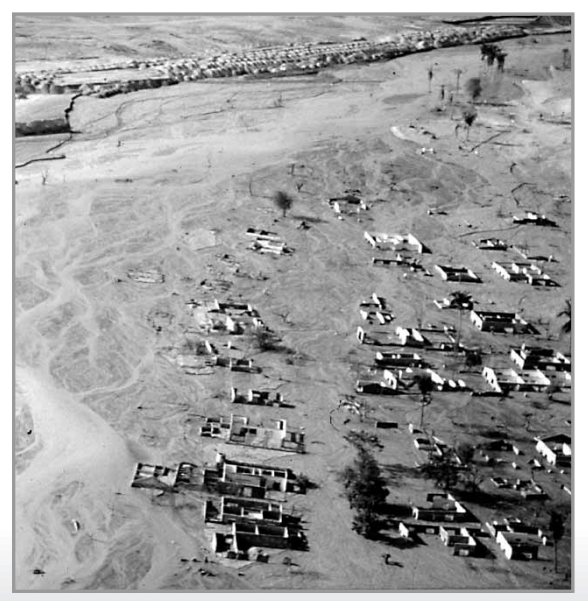

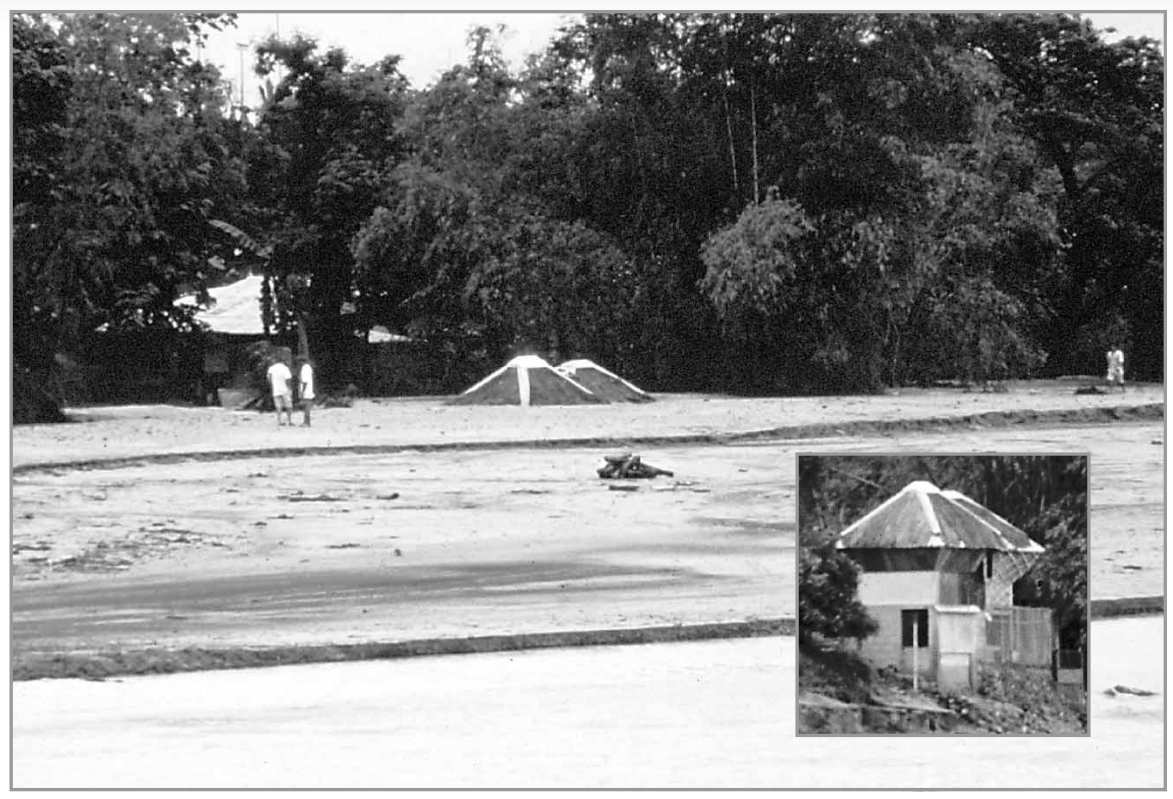

In August 1991, 2 months after Mount Pinatubo, Philippines, exploded in a cataclysmic volcanic eruption, this house (see roof) along the Sacobia-Bamban River 15 miles from the volcano was buried by a fast-moving mudflow of volcanic ash and debris (lahar) caused by heavy rains. Inset photo shows the house before it was buried. (Photos by Raymundo S. Punongbayan, Philippine Institute of Volcanology and Seismology.)

nology and Seismology (PHIVOLCS) intensified their monitoring of the volcano; they were soon joined by scientists from the U.S. Geological Survey (USGS) and other organizations. While evaluating the threat from the volcano, these scientists discovered that the gentle slopes surrounding Pinatubo had largely been created by countless giant mudflows of volcanic debris (lahars) from the powerful ancient eruptions that built the volcano. They also concluded that lahars would again rush down Pinatubo's slopes in its next major eruption, threatening the communities that were built while it slumbered.

\section{Nature and Causes of Lahars}

Explosive eruptions can deposit huge amounts ash and other volcanic debris on a volcano's slopes. Lahars form when water from intense rainfall, melting snow and ice, or the sudden failure of a natural dam, mixes with this loose volcanic material, creating mudflows that can be particularly dangerous and destructive. Although lahars contain at least $40 \%$ (by weight) volcanic ash and rock

The village of Lourdes, built on lowlands 15 miles northeast of Mount Pinatubo, was inundated by giant, fast-moving mudflows of volcanic debris (lahars) in the months following the volcano's cataclysmic June 1991 eruption. Since that eruption, lahars have destroyed the homes of more than 100,000 people in the area surrounding Pinatubo. fragments - making them dense and viscous like wet concrete- they actually flow faster than clear-water streams. These mudflows can rush down the flanks of a volcano at speeds as great as 40 miles (65 kilometers) per hour and can travel more than 50 miles (80 kilometers). Lahars that contain the most debris (as much as 90\%) move the fastest and are the most destructive.

Conditions that Create Lahars at Pinatubo

Annual rainfall at Mount Pinatubo ranges from 80 inches (2,000 millimeters) on the volcano's northeast flank to more than 160 inches (4,000 millimeters) on its summit and southwest flank. Nearly all of this rain falls during the time of the southwest monsoon (June to September) and the overlapping typhoon season (June to October). Rainfall during typhoons can be as intense as 2 inches (50 millimeters) per hour. Since the volcano's cataclysmic June 1991 eruption, the maximum rainfall at Pinatubo in one 24-hour period was more than 30 inches (780 millimeters) - as much rain as many parts of the United States receive in a whole year!

Ash and other deposits from Mount Pinatubo's 1991 eruption destroyed or buried much of the lush vegetation that had covered the volcano. When rainfall on Pinatubo exceeded about 0.5 inches (12 millimeters) 
in 30 minutes, rapid runoff down the still bare slopes quickly grew into torrents that became lahars by eroding these deposits. Fortunately, vegetation is beginning to grow on the 1991 deposits, and new stream channels are becoming established, reducing the runoff and erosion that create lahars.

\section{Lahars at Pinatubo Since 1991}

The volume of Pinatubo's lahars staggers the mind. In the first few years following the cataclysmic 1991 eruption, they have deposited more than 0.7 cubic miles ( 3 cubic kilometers; equivalent to 300 million dump-truck loads) of debris on the lowlands surrounding the volcano, burying hundreds of square miles of land. During heavy rains, lahars at Pinatubo can transport and deposit tens of millions of cubic yards of mud in a single day.

When the largest and fastest lahars reach the lowlands surrounding Pinatubo, they have speeds of more than 20 miles (32 kilometers) per hour, are as much as 30 feet (10 meters) thick and 300 feet ( 100 meters) wide, and can transport more than 35,000 cubic feet (1,000 cubic meters) of debris and mud per second. Within minutes, such powerful lahars can erode many feet into the banks or floor of a channel. They can carry large boulders, cars, or even bridges and can destroy or bury almost anything in their paths. When lahars reach low-lying areas, they spread out, slow down, and deposit their vast loads of debris over many square miles.

One particularly dangerous type of lahar has occurred at Mount Pinatubo as a result of the damming of stream channels and tributary valleys by the 1991 ash deposits or by subsequent lahars, creating temporary lakes. After a few weeks or months, the lakes overtop and quickly erode through their dams, releasing large volumes of water that generate major lahars. Because these large and powerful mudflows can occur without warning, even when there is no rain, they are among the most dangerous of Pinatubo's lahars. One lake on the Pasig-Potrero River, on the volcano's east flank, has formed and broken out three times (1991, 1992, and 1994), creating giant lahars that have killed dozens of people.

\section{Mitigation Efforts and Continuing Hazards}

When Pinatubo erupted in 1991, stream channels were small and were quickly filled by lahars deposits. Civil engineers

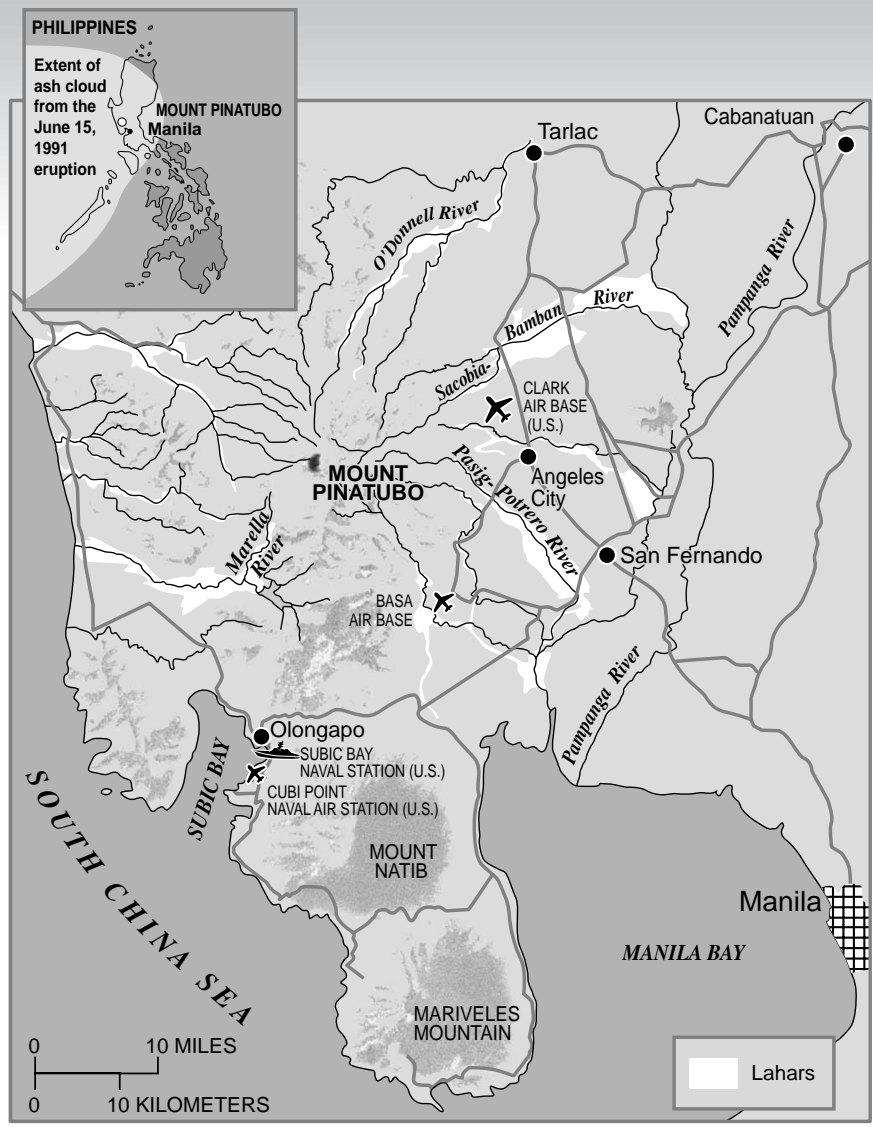

Within hours of Mount Pinatubo's explosive June 15, 1991, eruption, heavy rains began to wash the ash and debris deposited by this explosion down into the surrounding lowlands in giant, fastmoving mudflows called lahars. By 1993, lahars had already caused more devastation in the lowlands than the eruption itself. Fortunately, a system to monitor and warn of lahars was rapidly established in the days following the eruption by the Philippine Institute of Volcanology and Seismology, U.S. Geological Survey, and other organizations. This system has saved hundreds of lives by enabling warnings to be sounded for most but not all major lahars at Pinatubo. (U.S. bases have reverted to Philippine control since 1991.)

raced to trap the sediment behind small dams and to confine it between levees, but most of these measures were too small to contain the lahars. Near the base of the volcano, lahars eroded whole city blocks, and in the lowlands they inundated and buried entire towns.

Since the 1991 eruption, lahars from Pinatubo have destroyed the homes of more than 100,000 people. With most old stream channels filled, lahars can now spread widely on the gentle slopes and lowlands surrounding Mount Pinatubo, threatening successors to the early dams and levees. Fortunately, by 1995, the volume of material carried by Pinatubo's lahars had already decreased to less than a quarter of that carried in 1991, and new towns had been built on high ground for many of those displaced or threatened by lahars. Nonetheless, 100,000 people remain at risk from the volcano's lahars.

\section{Lahar Warnings}

Once the potential for lahars at Mount Pinatubo was recognized, scientists quickly prepared a preliminary hazard map. Since mid-June 1991, when violent eruptions triggered the volcano's first lahars in 500 years, a system to monitor and warn of lahars has been in operation. Radiotelemetered rain gauges provide data on rainfall in lahar source regions, acoustic flow monitors on stream banks detect ground vibration as lahars pass, and manned watchpoints further confirm that lahars are rushing down Pinatubo's slopes. This system has enabled warnings to be sounded for most but not all major lahars at Pinatubo, saving hundreds of lives.

Chris Newhall, Peter H. Stauffer, and James W. Hendley II Graphic design by Sara Boore and Susan Mayfield

\section{COOPERATING ORGANIZATIONS}

Armed Forces of the Philippines National Disaster Coordinating Council, Philippines

Philippine Institute of Volcanology and Seismology U.S. Agency for International Development United States Air Force United States Navy

\footnotetext{
For more information contact: U.S. Geological Survey Cascades Volcano Observatory 5400 Mac Arthur Blvd., Vancouver, WA 98661 Tel: (360) 696-7693, Fax: (360) 696-7866 http://volcanoes.usgs.gov/

See also The Cataclysmic 1991 Eruption of Mount Pinatubo, Philippines (USGS Fact Sheet 113-97)

U.S. Geological Survey Fact Sheet 114-97 1997
} 